\title{
The Experimental Study of Teaching games for Understanding in College Football Teaching
}

\author{
Chengwei Yang \\ Physical Institute \\ Sichuan Normal University \\ Chengdu, Sichuan, China \\ e-mail:530458906@qq.com
}

\author{
Peng Lu \\ Physical Institute \\ Sichuan Normal University \\ Chengdu, Sichuan, China \\ e-mail:1361770550@qq.com
}

\begin{abstract}
The "teaching games for understanding" is very important in football teaching. It could promote the reform of physical courses and improve the teaching quality of physical courses in colleges. It had indicated that the theory of "teaching games for understanding" is according with the cognition and psychological characteristics of students, and this theory is corresponding to the law of football education. The theory of "understanding method of teaching" not only improve the basic skills, the ability of use the skills, and the level of consciousness of students, but also play an important role in understanding of theoretical knowledge and group cohesion. Furthermore, it has also played a positive role in the cultivation of students' interest in learning, stimulation of the learning initiative. So the suggestion is to improve and promote the understanding method of football teaching in colleges and universities and all kinds of ball games teaching.
\end{abstract}

Keywords-understanding method of teaching; experimental study; football course

\section{PREFACE}

Football is a kind of technical and tactical complex structure, antagonistic highly ornamental group project. However, in the traditional teaching idea of Chinese football, people regard the sport skills as the core of teaching and regard a single technology appraisal as a measure of the level of football standards without confrontation. It did not reflect the football idea of outstanding against and combining actual modern football. This is a common problem in our country for all levels of football teaching and training in the long term and also is one of reasons for China's overall level of football behind. Because of the deep influence of exam-oriented education, college football teaching regards the examination of the segment as teaching core. And the teaching methods are quite old and the research is very lack of teaching. Since 1999, there have been about 34480 thesis which is with "football" as the research object and about 180 thesis which is with "football teaching method" as the research object, accounted for $0.5 \%$. "The lack of related research in football teaching method" makes the football teaching and training in China is lack of theoretical basis. British scholar Bunker and Thorpe developed a new sports teaching method -- the ball and understand the teaching method from ball games teaching in 1980s. It emphasizes to simplify the ball game and competition as the center, promote students' learning tactics and skills in the game and cultivate the ability to solve problems in all kinds of ball games [1]. It exerted a profound influence on the teaching of ball games and was hailed as the new trend of teaching reform of ball. To deepen the reform of university physical education curriculum, improve teaching quality and effect of physical education in colleges and universities, this study attempts to put understand the teaching method into the practice and theory of football course teaching. This will provide reference for the reform of teaching contents and teaching methods, teaching model of ball courses.

\section{RESEARCH OBJECT AND METHOD}

\section{A. Document research}

Refer to the football, education, teaching theory, sociology, psychology and some literature data and research results that is about the teaching method of grasping and related with this study. Then summarize it.

\section{B. Questionnaire}

Through access to literature study of football teaching effect, organize the Football Teaching Effectiveness Questionnaire "-1 ". Then we handed it to 12 experts who are engaged in volleyball teaching for many years to confirm the contents of the questionnaire validity. They were deleted 2 and retained 33 items among 35. "Football Teaching Effectiveness Questionnaire -2 ". And test-retest reliability testing of small samples, the results shows that the 33 item 30 item 30 days test-retest reliability between 0.6 and 0.8. Finally, evaluate the experimental group and teaching group using the prepared questionnaire.

\section{Mathematical statistics}

Using SPSS 16.0 software, treat conventional statistical data.

\section{Experimental teaching method}

Using SPSS 16.0 software, treat conventional statistical data. 
1) The subjects: In 100 male students of Sichuan Normal University Sports Institute 2011 level of football class as the experimental object, a total of 4 classes, two classes are the experimental group, the other two are the control group, each class is 25 .

\section{2) Measurement tools}

a) Basic test method of the football skills: Test rules football techniques were in accordance with Sichuan Normal University Physical Institute football course evaluation method, test project to dribble around the shot, head the ball, set-piece ball and the ball.

b) Evaluation method of performance and use of technical and tactical ability of competition: According to the sports teaching expert Griffin, Mitchel1 and Oslin created the sports game performance assessment tool GPAI in 1997. Altogether there are 7 aspects, such as index standard, choice, skill execution, support the getaway, man-to-man defense, fill with and position adjustment. They include cognitive and skill areas both the idea and action of the ball and not the ball, so one can observe player more complete [2]. This study remove the five specific indicators on the basis of the specific characteristics of soccer ball movement and the competition, which are "standard", "choice", "skill execution", "support the get-away" and "defensive cover" and 20 points for each score. The Kendall coefficient of concordance of 5 project in $0.84-0.93$. That is evaluated by 4 senior teachers and the inter-rater consistency coefficient is higher.

c) The teaching of football course questionnaire: Self-compiled "Questionnaire" football course teaching situation is divided into the learning attitude, learning effect, teaching methods and learning interest in order to investigate the students' subjective. It includes 14 items and relates to the initiative of learning, learning subject consciousness, interaction, mutual help and learning, the survey of classroom atmosphere. Through analysis, we get feedback information.

d) Group cohesion:Using Group Environment Questionnaire (GEQ) organized by Carron and others, we investigated students' views of groups and experience in the team. The scale includes 24 items. It depends on a total score of group to analysis cohesion level. The experimental group and the control group cohesiveness of the internal consistency test clone Bach a coefficients were 0.95 and 0.78 .

3) Experimental design: two groups of students football technical achievement test results before the experiment (Table 1)
TABLE I. TWO GROUPS OF STUDENTS FOOTBALL TECHNICAL ACHIEVEMENT TEST RESULTS BEFORE THE EXPE

\begin{tabular}{|c|l|l|l|l|ll|}
\hline group & $\begin{array}{c}\text { Number } \\
\text { of people }\end{array}$ & $\begin{array}{c}\text { dribble } \\
\text { around } \\
\text { the } \\
\text { shot(s) }\end{array}$ & $\begin{array}{c}\text { set- } \\
\text { pieces } \\
\text { RBI( }\end{array}$ & $\begin{array}{l}\text { Pop and } \\
\text { tip }\end{array}$ & head shot \\
\hline $\begin{array}{c}\text { Experi } \\
\text { mental } \\
\text { group }\end{array}$ & 50 & $\begin{array}{l}14.25 \\
\pm 2.8\end{array}$ & $\begin{array}{l}1.8 \\
1.23\end{array}$ & $\begin{array}{l}7.9 \\
5.63\end{array}$ & $\begin{array}{l}1.4 \\
1.07\end{array}$ & \pm \\
\hline $\begin{array}{c}\text { Contro } \\
\text { l group }\end{array}$ & 50 & $\begin{array}{l}14.12 \\
\pm 2.44\end{array}$ & $\begin{array}{l}1.8 \\
1.14\end{array}$ & $\begin{array}{l}7.3 \\
6.09\end{array}$ & $\begin{array}{l}1.6 \\
1.26\end{array}$ & \pm \\
\hline $\mathbf{T}$ & & 0.33 & 0 & 0.229 & -0.381 \\
\hline $\mathbf{P}$ & & 0.596 & 0.601 & 0.883 & 0.673 \\
\hline
\end{tabular}

Before the experiment we test each index the object : dribble around the shot, set-pieces RBI, ball and ball shot. (see Table 1) The results show that there was no significant difference between the experimental group and the control group ( $\mathrm{P}>0.05)$, so that the test in line with the requirements of the experiment. In the experiment, the control group used the traditional teaching mode (announced class tasks and content, teacher demonstration, teacher practice, students practice with teachers to correct mistakes, summary). Because of the long course hours and the difficulties of the understanding teaching mode is larger, so the experimental group spends 40 hours using comprehends the teaching mode (project introduction to match overview, tactical awareness training, instantaneous assertiveness training, skill demonstration, action), insert with traditional teaching mode with 40 hours. We cope with these data of the subjects after the experiment.

\section{EXPERIMENTAL RESULTS AND ANALYSIS}

A. The affection of "understanding method of teaching" introduction of football course on the technical level of the students football

TABLE II. AFTER THE EXPERIMENT, TWO GROUPS OF STUDENTS FOOTBALL TECHNICAL ACHIEVEMENT TEST RESULTS

\begin{tabular}{|c|c|c|c|c|c|}
\hline group & $\begin{array}{l}\text { Number } \\
\text { of people }\end{array}$ & $\begin{array}{c}\text { dribble } \\
\text { around } \\
\text { the } \\
\text { shot(s) }\end{array}$ & $\begin{array}{c}\text { set- } \\
\text { pieces } \\
\text { RBI( }\end{array}$ & $\begin{array}{l}\text { Pop and } \\
\text { tip }\end{array}$ & head shot \\
\hline $\begin{array}{c}\text { Experi } \\
\text { mental } \\
\text { group }\end{array}$ & 50 & $\begin{array}{l}12.22 \\
\pm 1.5\end{array}$ & $\begin{array}{c}3.82 \text { 士 } \\
1.03\end{array}$ & $\begin{array}{c}29.48 \text { 士 } \\
4.47\end{array}$ & $\begin{array}{c}4.42 \text { 士 } \\
0.841\end{array}$ \\
\hline $\begin{array}{l}\text { Contro } \\
\text { I group }\end{array}$ & 50 & $\begin{array}{l}12.71 \\
\pm 1.2 \\
\end{array}$ & $\begin{array}{c}3.21 士 \\
1.11 \\
\end{array}$ & $\begin{array}{c}31.56 \pm \\
3.51\end{array}$ & $\begin{array}{c}3.53 \pm \\
1.01 \\
\end{array}$ \\
\hline $\mathbf{T}$ & & -0.795 & 1.229 & -0.24 & 2.077 \\
\hline $\mathbf{P}$ & & 0.43 & 0.21 & 0.814 & $0.052 *$ \\
\hline
\end{tabular}

Statistical analysis (see Table 2), the test scores of dribbling around the shot, RBI and header shot placement from experimental group are better than the control class. There was a significant difference between the test head shot results ( $\mathrm{P}<0.05)$, but the ball test scores of control 
group are better. That is to say, the teaching of the use of the overall effect is better than the control group.

Sports technology is to give full play to athlete's physical ability and method of performing actions reasonably and effectively. Sport skills are abilities those are to complete the action according to certain technical requirements. Sports skill teaching is the main form of physical education teaching, is also one of the basic goals of [3]. After a semester of football study, experimental group and control group football technical level has improved. Therefore, the improvement in the experimental group and the control group students are very obvious. The students in the experiment group in addition to hit one, the other result is higher than that of control group. This shows that the introduction of "understanding method of teaching" to football lesson has more obvious effect on improving the students' level of football technique. The reasons are that there must have the certain technology base to participate in the competition. In order to get more happiness and success in the game, the students will consciously in peacetime to strengthen technical training and in the game to be used and improved. Through the repeated practice and constantly testing in the game, promote the continuous improvement of technology. And the ball in the project, the control group scores higher because there is more time in the traditional method of teaching practice. So the technology practice level should be improved also need time to accumulate, the traditional teaching method in the technology practice method also has certain value

B. "Understanding method of teaching" lead in football course affects on the use of technology student competition ability and tactical consciousness level

TABLE III. THE RESULTS OF THE MAIN INDEXES OF TWO GROUPS OF STUDENTS AFTER THE EXPERIMENT

\begin{tabular}{|c|c|c|c|c|c|}
\hline group & $\begin{array}{c}\text { index } \\
\text { standard }\end{array}$ & choice & $\begin{array}{c}\text { skill } \\
\text { executi } \\
\text { on }\end{array}$ & $\begin{array}{c}\text { support } \\
\text { the get- } \\
\text { away }\end{array}$ & $\begin{array}{c}\text { defensive } \\
\text { cover }\end{array}$ \\
\hline $\begin{array}{c}\text { Experi } \\
\text { mental } \\
\text { group }\end{array}$ & $\begin{array}{c}16.31 \pm 1.6 \\
35\end{array}$ & $\begin{array}{c}16.25 \pm \\
2.079\end{array}$ & $\begin{array}{c}16.4 \pm 2 . \\
415\end{array}$ & $\begin{array}{c}15.85 \pm 1.4 \\
24\end{array}$ & $\begin{array}{c}16.35 \pm 1.7 \\
55\end{array}$ \\
\hline $\begin{array}{c}\text { Contro } \\
\text { l group }\end{array}$ & $\begin{array}{c}14.65 \pm 1.9 \\
8\end{array}$ & $\begin{array}{c}14.75 \pm \\
1.992\end{array}$ & $\begin{array}{c}13.65 \pm \\
1.98\end{array}$ & $\begin{array}{c}13.95 \pm 18 . \\
77\end{array}$ & $\begin{array}{c}14.55 \pm 1.9 \\
3\end{array}$ \\
\hline $\mathbf{T}$ & 2.963 & 2.526 & 3.938 & 3.606 & 3.191 \\
\hline $\mathbf{P}$ & $0.005^{* *}$ & 0.016 & $0.00^{* *}$ & $0.001 * *$ & $0.003 * *$ \\
\hline
\end{tabular}

The 4 football teaching competitions between the experimental group and the control group at the end of the course stage, the results are the experimental group won by a large margin. Through statistical analysis of 5 main indexes of two games to individual student's (see Table 3), it is not difficult to see that it exist very significant differences in "standard", "choice", "skill execution.", "support the get-away" and "defensive cover" and the students in the experimental group performance is better than the control group significantly.
Teaching practice football game is an important process and is also the effective way to consolidate the basic tactics. It is an important means for teachers to get feedback information and the teaching effect and is also the important process that the student will be indirect experience into direct experience [4]. Through statistical analysis of 5 main indexes of two classes of students (see Table 3), it is not difficult to see that the indicators of students in the experimental group using technology in the competition ability and tactical awareness levels are significantly better than the control group. The standard, defensive cover average scores are high in experimental group. It indicates that the students in the experimental group are active defense and fully understand the essence of the defense. Meanwhile, they have good team spirit, strong sense of coordination and complement. Technical performance is so good that the students confidence is high and the play of the technology is stable. The get-away support score is high. It indicates students have the consciousness of team, the tacit understanding with the companion and more skilled personal and collective tactics. In addition, the performance results from the two groups is close, choice can be enhanced after a long football training and competition. The short time teaching is not enough to significantly improve the decision level. In traditional teaching, students usually have good technical level but they will not be able to play in the game. That is because the usual practice less and it is lack of self-confidence when the race mental load is increasing and it will affect the level of play inevitably. "Understanding method of teaching" attaches great importance to cultivate students' competition ability. Through the massive teaching competition not only meet the students to combat the desire but also train the football consciousness of students and improve the ability of using of tactics reasonably. The teachers explain it with clear aim and plan according to the competition so that the students can use the skills and tactics correctly and timely guidance and enhance mutual understanding and the understanding to the combination of theory with practice and constantly improve their own competition ability. So It is good for improving students' football consciousness "understanding method of teaching" lead in football teaching and can improve the students' ability to play effectively.

C. The "understanding method of teaching" lead in football course affect on the football contest rule and judge method and theory of knowledge that students master

TABLE IV. TWO GROUPS OF STUDENTS THE THEORY TEST STATISTICS AFTER THE EXPERIMENT

\begin{tabular}{|c|c|c|c|c|}
\hline factor & $\begin{array}{c}\text { experimental } \\
\text { group }\end{array}$ & $\begin{array}{c}\text { control } \\
\text { group }\end{array}$ & $\mathbf{T}$ & $\mathbf{P}$ \\
\hline theory & $81.11 \pm 2.65$ & $78.02 \pm 3.69$ & 2.61 & $0.042^{*}$ \\
\hline \multicolumn{4}{|c}{} \\
\hline
\end{tabular}

The results show (Table 4) that the experimental group and the control group showed significant difference 
$(\mathrm{P}<0.05)$ about the theory of the assessment after the experiment. That indicates the comprehension the teaching method has a larger advantage for students to master the football contest rule and judge method and theory of knowledge.

Football theory teaching and on the refer law rote on the traditional teaching method for $4-5$ hours. That is unable to make the students grasp and understand the rules of a contest judge method and theory of the football knowledge after years of practice. Only through the game and judicial practice and combined with the theories and classroom discussion, it is more conducive for the students to master the theory of knowledge. Comprehends the teaching method has faster and deeper cognition on the football. That reflects more active exploration, the participation of teachers and students and students and students communication. The classroom atmosphere helps students to cognitive principle of football and inspired students to understand football rules of its own initiatively in the teaching competition. It improves students' abilities. At the same time it improves their professional theory and the referee method cognition level.

\section{Comprehends the teaching method influence on the group cohesion}

TABLE V. GROUP COHESION STRENGTH OF DIFFERENCE COMPARISON TABLE BETWEEN THE EXPERIMENTAL CLASS AND THE CONTROL CLASS

\begin{tabular}{|c|c|c|c|c|}
\hline factor & $\begin{array}{c}\text { Measured value } \\
\text { on experimental } \\
\text { class }\end{array}$ & $\begin{array}{c}\text { Measured } \\
\text { value on } \\
\text { control class }\end{array}$ & $\mathbf{T}$ & $\mathbf{P}$ \\
\hline $\begin{array}{c}\text { Group } \\
\text { cohesion }\end{array}$ & $0.1792 \pm 0.581$ & $-.0322 \pm 0.631$ & 2.151 & $0.043^{*}$ \\
\hline
\end{tabular}

The results show (Table 5), the students in the experimental class after a semester teaching, group cohesiveness was significant higher than the control class, which shows that multiple teaching method is helpful to improve group cohesion.

Comprehends the teaching method teaching process mainly in group games and competitions, grades and groups of students is closely related to the performance, group members have common learning objectives. At the same time each individual small groups communicate contest, students have a strong sense of belonging and identity of the group, will own tightly into groups, interpersonal interaction with other members of the group, the group members to study together, progress together, but also fully mobilize the enthusiasm of students, make students study and Practice on the mutual encouragement, cooperative and interactive atmosphere, cultivate the team cooperation spirit, improve team cohesion.

\section{E. Effect of comprehends the teaching method on students' teaching effect.}

At the end of the experiment on the occasion, with selfcompiled "Questionnaire" football course teaching situation, carries on the investigation to the students' interest in learning, the main experience, teaching methods and classroom atmosphere (see Table 6), the results show, interest in learning, the main experience, teaching methods and classroom atmosphere, the experimental group and the control group had significant difference. Students' interest of the experimental group in learning more intense, more enjoyable and exciting experience, the teaching mode of higher degree of satisfaction.

TABLE VI. COMPARISON BETWEEN THE EXPERIMENTAL CLASS AND THE CONTROL CLASS LEARNING INTEREST, BODY EXPERIENCE, TEACHING METHODS AND CLASSROOM ATMOSPHERE EVALUATION

\begin{tabular}{|c|c|c|c|c|}
\hline content & $\begin{array}{c}\text { Learning } \\
\text { interest }\end{array}$ & $\begin{array}{c}\text { Subjective } \\
\text { feelings }\end{array}$ & $\begin{array}{c}\text { Teaching } \\
\text { methods }\end{array}$ & $\begin{array}{c}\text { class } \\
\text { atmosphere }\end{array}$ \\
\hline $\begin{array}{c}\text { experimental } \\
\text { group }\end{array}$ & $1.811 \pm 0.491$ & $1.752 \pm 0.754$ & $2.11 \pm 0.422$ & $2.06 \pm 0.439$ \\
\hline Control group & $1.971 \pm 0.498$ & $2.07 \pm 0.397$ & $2.32 \pm 0.491$ & $2.34 \pm 0.615$ \\
\hline $\mathbf{T}$ & 2.571 & 2.031 & -2.071 & -2.114 \\
\hline $\mathbf{P}$ & $0.011^{*}$ & $0.045^{*}$ & $0.043^{*}$ & $0.039^{*}$ \\
\hline
\end{tabular}

(** Indicates $\mathrm{P}<0.001$, * indicates $\mathrm{P}<0.05$ )

From the questionnaire of the experimental group results can be seen, comprehends the teaching method can effectively improve the students interest in football teaching, enhance the students' enthusiasm and initiative. Modern physical education teaching is not only confined to the immediate effect, should pay more attention to the cultivation of students' self-exercise ability, master the methods of training, the habit of exercise course, students not only the future sports teacher is ordinary members of society, so the football teaching should not only be confined to the immediate effect, more attention should be paid to and improve to cultivate students' comprehensive quality, especially pay attention to training students' ability of self-exercise, master the ways to exercise, the exercise habit, benefit their life. Comprehends the teaching method is like starting form from students, stimulate their learning Gas Volleyball interest and enthusiasm, to communicate with each other, mutual discussion, common experience, common experience and student activities, through targeted education so that every student progress, inspired students thinking, let them learn some football skills at the same time, also enable them to enjoy the pleasure brought by sports. The students' interest shown in motor learning and enthusiasm has been successfully transformed into a habit of their own, so as to improve their ability, and laid a solid foundation for lifelong physical exercise.

\section{CONCLUSIONS AND RECOMMENDATIONS}

\section{A. Conclusions.}

1) Football course in the understanding method of teaching can promote students to learn and master the basic technique, is helpful to improve the level of football technique.

2) In the football course in introducing comprehends the teaching method, improve the ability of students to use 
technology in the game, to cultivate the students' consciousness of tactics.

3) In the football course in introducing comprehends the teaching method for students to master the football contest rule and judge the method and theory of knowledge effect.

4) Comprehends the teaching method is more beneficial to the cultivation of team spirit, improve team cohesion.

5) Comprehends the teaching method can stimulate students' interest and motivation, so that students have a clear learning objectives, stimulate the students' enthusiasm, initiative and creativity, in accordance with the psychological characteristics of contemporary college students.

\section{B. Suggestions.}

1) Comprehends the teaching method of comprehensive quality of football teachers put forward higher requirements, therefore, to constantly enrich and improve the professional knowledge and skills, strengthen the awareness and understanding of football.
2) Sports colleges and universities sports teaching application and understand the teaching method, make the traditional technical teaching advantages, the combination of the two can play a greater use of teaching effect.

3) Comprehends the teaching method as the ball teaching innovation methods, fully embody the quality education, should be more in-depth study, improve the relevant theory and system, in order to improve the teaching quality of service all kinds of ball games.

\section{REFERENCES}

[1] R.Thorpe, Bunker, L.Almond. Rethinking games teaching[M].Loughborough: University of Technology,1986.

[2] Griffin, Mitchell, Oslin. Teaching sport concepts and skills: A tactical games approach[M]. Champaign, IL:Human Kinetics, pp. 118,1997

[3] Tian Maijiu, sports training [M],. People's sports press, 2000

[4] Zhang Nan, college basketball elective course "understanding method of teaching" experiment [Dissertation], Beijing Sport University, 2002

[5] Liao Yuguang, ball teaching one comprehends the teaching method of [M], the Hong Kong Institute of education, 2002 